\title{
Chinua Achebe, A Legend and A Bed-Rock of Today`S Education
}

\author{
Dr. JoeBarth C. Abba \\ Lecturer, Anambra State University \\ Department of Religion and Society, Nigeria
}

\begin{abstract}
Professor Chinua Achebe is a great Nigerian African popular legend. He is regarded as the "father of modern African literature" because of his great work, Things Fall Apart translated into more than 60 languages of the world. We shall delve more on his knowledge, his wisdom and his fruitful contributions and postulations to the academic world especially his being an internationally celebrated man as a Novelist, Playwright, Essayist and a Poet. The 82 years old world classic novelist gave up ghost on 21 March 2013; stirred who up the world-all corners of the globe on the news his passing away to the great beyond. As the best rock of African Nigerian education, we will see in this essay his life, his being a colossus and a legend of learning and writing; and his motivational truism of life. We shall then conclude with Chinua Achebe's expected challenges and expectation for the advancement of Nigerian-African education and excellence.
\end{abstract}

Key: Chinua Achebe, Modern African, Culture, Education, Legend

\section{INTRODUCTION}

The iconic author of the adored classic novel, Things Fall Apart is Chinualumogu Albert Achebe, an Igbo, native of Ikenga-Ogidi in Anambra State of Nigeria, West Africa, born on November 16, 1930. Achebe would have indeed turned 83 this year, the news of his death shattered the serene atmosphere and this marks the nuncdimitis of the pioneer African writing. The renowned Nigerian author and literary icon, Prof. Chinua Achebe died after a brief illness in Boston, Massachusetts in United States of American on March 21, 2013 and was buried on May 23, this same year, an interval of 3 months after his demise. The up-roar, the out-pouring of emotions from all corners of the globe in the wake of the passing away of Chinua Achebe reached every ear and Media Industries of the World Communicative bodies. As a global citizen and a prolific literary icon and great son of Africa, he was ever duty conscious and foresighted. For Nadine Gardiner he had a brilliant mind and bold spirit. We saw in Chinua Achebe not only as a herald and harbinger for Nigeria future but also a livelihood depicting a typical moral avatar, a simple literary sheriff illuminating with his brain and pen. He was a non-stop reminder to his fellow Nigerian citizen the waste land of nation's leadership porously trapped in corruption and ineptitudeness.

In the eyes of many mortals, Chinua Albert Achebe has not died but merely translated to paradise fecund musses. He was a superman for nation building.

The heroic values of Achebe burst into literary fame with the publication of his first novel Things Falls Apart, in 1958. He is fondly regarded as the "father of modern African literature". The internationally celebrated writer Prof. Chinua Achebe was a Novelist, Play writer and a poet who contributed immensely to education and development of African literature in his lifetime. Actually his Things Fall Apart brought Nigeria fame by "attaining worldwide 
recognition". Nigeria loses a gem and an achiever of historical developments and agent of change for the whole populace.

Among the kern salient words in his last speeches and valedictory words and hearty wishes were that the Nigeria Nation would be free of corruption as well as line up to the expectation of its citizens. Nelson Mandela described him as the 'writer in whose company the prison wall fell down'. Actually, with his pen, writings did seek and succeeded in liberating souls and people who were captives of man's inhumanity to fellow men.

Achebe the African legend, a defender of black man's history had his work translated to our sixty world languages, read and studied by millions all over the world. That he lived in the hearts of those who loved him and love his great works of different epochs is surely the attainment of eternity, immortality and devout life. He won the love and heart and respects of many souls especially the academia. He improved peoples' knowledge of African culture and tradition through his pen apostolate and can always be understood by all discerning minds. Because of his moral love to humanity, he refused to share national honors with ill-godly millionaire's conscienceless-individuals.

As a master-story teller, the eagle on Iroko tree, he was always finely rooted in culture as reflected in his work and appearance. None the less, he remains the pride of Igbo race and paragon of Igbo nationalism and equally a paragon of virtue that bent no evil mind. He remains one of the African novelist, author and defender of African literature. A colossus of the literary world, he came, he saw and he conquered and through him and with him the literary sun was set at ease. His brilliancy and wisdom cum price performances made him move rather rapidly up the ladder and ultimately for a greater advancement.

Achebe was the founding editor of the African Writers Services under the aegis off Heinemann of London. For many years Achebe was a theoretician of development and change, fervently believed in the power of literature and the creative acts to heal and regenerate people and society.

He viewed literature as constituting landmark progress for African civilization and repossession of the patrimony looted and appropriated by European imperialist interest. Indeed, he regarded the Corpus of African literature as aesthetic and moral glue that bonded African people on the continent and the African Diaspora.

Achebe was indeed exposed to Western classics. He himself also recalls in his 'There was a Country' Reading these books was a transforming experienced. He as the author of the epic ground breaking novel "Things Fall Apart" Chinua Achebe means a lot to Nigeria and to Africa as a whole. Achebe was a fearless Nigerian, who said the truth as the way, it was, no matter whose ox is gored. One can always write volumes on the person, time and good works or monuments of the African literature the great born world acclaimed literary writer Prof. Chinua Achebe.

The success of things Fall Apart opened a new vista for not only Achebe and other writers of his generation from Nigeria, but across Africa, including Ngugiwa Thiong'o, Peter Abraham Mongo Bete', Camera L'aye to mention a few. As an academic, he has taught in renowned institutions in Nigeria and beyond, such as the Universities of Nigeria Nsukka, Connecticut, Dartmouth, Stanford and Brown, USA, where he died as the David and Marianna Fisher University Professor of Africana Studies and Literary Arts. He received over 20 honorary awards in his lifetime. One would say in death Achebe stands as a colossus, and perhaps even taller than he was in real life on earth. People admire Achebe's writing style and his storytelling 
techniques, though some of his works at times do provoke controversy like one of his book called "There Was a Country" He stirred the hornet's nest and bowed out joyously and triumphantly. He indeed left the stage when the oration was highest.

Achebe's sojourn on earth was a long and eventful journey for the 82years he lived. A native of Ogidi in the present Anambra State. Achebe's education at Government College, Umuahia, and the University of Ibadan shaped his literary and historical orientation. In fact, his primary exposure in his native Ogidi town as a school boy and Nekede, near Owerri prepared him for the long journey to greatness. At that much ripped age, he had his eyes on the historical and cultural happenings round him, which found their way to his writings, evidenced in his constant backward glaring to the Igbo cosmology and the dualities.

\section{Achebe`s Life Style and Education and Educational Goal of a Legend}

Achebe spent many years of his life on earth also in the United States, and for several years in the 1970's He came back to Nigeria and later returned to USA in 1990 after a car accident that left him partially disabled. His life style and educational goal as a legend is very attractive and challenging. Achebe crafted Things Fall Apart, his bestselling classic which etched his name permanently on the global literary chants. The grounds well of reception and rake reviews the book enjoyed were dumbfounding, even shocking to himself the author. Actually, Achebe himself admitted that he didn't dream of a cult readership of his famed book, when he said "for me, at least, I can declare that when I write Things Fall Apart, I couldn't have told anyone the day before it was accepted for publication that anyone was going to read it... But my brotherin-law, who was not a particularly voracious reader, told me that he read the novel, through the night and it gave him a terrible headache the next morning. And I took that as an encouraging endorsement. In Achebe in "There Was a Country his latest controversial book (Adebayo: 18). The Things Fall Apart novel has sold more than 12 million copies around the world and has been translated into over 60 languages. Achebe indeed had ever continued to give the world and all educationists a piece of himself. More on his literary prowess are inter alia, No Longer at Ease, Arrow of God, and A Man of the People and Anthills of the Savannah. On the memory lane, Achebe had occasion to show his discontent with the state of affairs in Nigeria. An example, was when the region of Biafra broke away from Nigeria in 1967, Achebe became a supporter of Biafra Independence and acted as ambassador for the people of the new nature. When the war ravaged the populace, and as starvation and violence took their tolls, he appealed to the people of Europe and the Americas for help. And when Nigerian government retook the region in 1970, he involved himself in political parties but soon resigned due to frustration over the corruption and elitism he witnessed. It was crystally clear, that Achebe rejected for two consecutive times offers of a national honor on the ground of the underdevelopment and unenviable style of governance in his fatherland. In 2004, rejecting the award of the Commander of the Federal Republic, (CFR), by the administration of former President Olusegun Obasanjo, saying "Nigeria's condition today under your watch is, however, too dangerous for silence, I must register my disappointment and protest by declining to accept the high honor awarded me in the 2004 honor list.

A re-occurrence, chanced again as the literary guru repeated his steak in 2011, when President Good luck tried to bestow on him the national award of DRD. In his characteristic manner, Achebe retorted that the country's numerous, socio-political challenges have not been addressed, let alone solved". Despite some encounters, criticisms and confrontations he Achebe came as a literary giant with a sound mind of his own. Achebe remained a consummate writer, and his style of writing has a deep inflection from oral folk tales. As an avid reader and writer, he writes as if readers are just right beside him, such is the artistry, he used in teeing off There Was a Country. He was a refugee from a killer civil war, remained a strong man. His works and 
legacies are not likely to die. He has ignited an army of protégées who idolizes him. His own words on this core "The triumph of the written word is often attained when the writer achieves union and trust with the reader who then becomes ready to be drawn deep into unfamiliar territory walking in borrowed literary shoes so to speak, towards a deeper understanding of self or society or of foreign peoples, cultures and situations. Achebe left his footprints as a very brilliant student having obtained full scholarship for his secondary education. The United States, on passing the resolution as part of its duty to "pay tribute to the lives of those esteemed individuals of internationally renowned, who distinguished themselves through their life's works". Achebe also lived in New York since 1990 till he died on Thursday March 21, 2013. The New York State resolution on Achebe was titled, "Fall Text of Resolution J 1186 2013; Legislative Resolution mourning the death of paramount novelist Chinua Achebe, founder and pioneer of African Literature". This resolution showed he distinguished himself in his profession and by his sincere dedication and substantial contribution to the welfare of his community.

Achebe committed his excellence and spirit of humanity into all fields of enterprise, including charitable and civic endeavors. Achebe's global significance lies not only in his talent and recognition as a writer but as a critical thinker and essayist who has written extensively on questions of the role of culture in Africa along with the social and political significance of aesthetics and analysis of the post-colonial state in Africa.

The New York Senate rated Achebe highly saying that he left behind a legacy which would long endure the passage of time and would remain as a comforting memory to all he served and befriended. They as well noted that Achebe did live in United States for several years in the 1970's and returned in 1990 after a car accident paralyzed him.

Achebe's spirit will remain longer in life. In 1983, Achebe reflected on the decade of Nigeria's inability to achieve culto-social economic and technological transformation nearly 25 years after the attainment of independence from Britain. He traced the disease to the mental handicap of the elite to connect the technical graph of development to the science of inventive and creative thinking. The mind or intellect or story, Achebe's reason of the ideas of bold optimism and technologies that engender progress. He identified the trouble with Nigeria as the indolence of the leadership caused by the providential riches of oil, such that the country always believes in throwing chunks off money at problems.

Achebe realized most of his dreams as the Africa's foremost literary icon; he impacted on African literature and the continents political life. His books helped to foster the talent of countless writers in Africa's post-colonial era, they also inspired a number of Africa's current political leaders. His influence on the African political landscape grew stronger that three years ago, he started convening an annual colloquium at Brown University where he was a professor that brought together leaders, scholars and artists to discuss "strengthening democracy and peace on the African continent".

He succeeded in his systematic work, especially in first lineage of books which a collection of people, cultural heritage and values and their behaviors envisaged. Achebe's stories have charmed and counseled millions of people across the world. The stories and the academic researches they generated have canonized Achebe as one of the best story teller of all ages. He is adoringly regarded as the father of African fiction. We are today creating more greatly new Africa and 'Africans people', according to Prof. G. G. Dara Things Fall Apart has entered the lexicon of the world classics of literature and it is included in the 3,032 page and the Norton Anthology of World Masterpieces. 
His life style was always attractive and in order before embracing more global engagements, he packed much into the 1990/81 sessions. Thus, he organized the Okochi (dry season in Igbo language), festival to which he invited story tellers form the villages, in an attempt to make the university recognize the real oral literature. The vernacular recitals took place during the full moon and in the open-air Princess Alexandra Building- its roof was destroyed by bombs during the 1967-1970 Nigerian Civil War and the University decided to keep it that way were as a war relic. Achebe later said in upstate New York, USA, over a decade later, that the final duty he did before leaving Nigeria was to organize the Association of Nigerian Authors (ANA), in 1981. Achebe took the African story, the Nigerian story, out of the apparently warped view of colonial writers, exemplified in Joseph Comad and his ilk, and told it as it ought to be. His Things Fall Apart and the consequent trilogy became classics, not just in delivery but also in thematic and structural ingenuity.

Achebe's contemporaries at Ibadan included Wole Soyinka, JP Clark, Mabel Segun, Chris Okigbo, Chukwuemeka Ike, among others, scribers who cut their teeth very well as literary idols.

As a colossus in learning and writing, he realized that the journey to the realization of this masterpiece, Things Fall Apart, wasn't an easy ride. Faced by a series of rejections, he wasn't deterred. As the director of external broad casting at NBC, Achebe had more responsibilities and he wrote the manuscript of Things Fall Apart mostly at night. In this meaning he said: "I was seized by the story and I found myself totally ensconced in it. It was almost like living in a parallel realm, a dual existence not in any negative sense but in a way a hand has two surface united in purpose but very little in tone, character and structure".

Achebe's Things Fall Apart and his other books really straddled the firmament like a colossus, his reputation as a novelist, poet and essayist cast in gold. He was literary guru whose fame as a master story teller was legendry. His creative and virtues act of writing made his books in all the continents, sale in hot demand, and he became the writer's writer. No wonder the great novelist, Margaret Atwood called him "a magical writer-one of the greatest of the twentieth century. The poet Maya Angelou landed Things Fall Apart when he said that it is a book wherein all readers meet their brothers, sisters, parents and friends and themselves along Nigerian roads. No wonder, Bruce king commenting in introduction to Nigerian Literature described Achebe as the first writer to successfully transmute the conventions of the novel, an European, art form, into African literature. That is why Prof. Achebe was indeed a man of conscience and integrity, a man of the people whose memory deserves to be kept active.

A strong man who always stood for honesty, justice, self-determination, simplicity, courage and good governance. For him to have rejected national award twice means that he is a man of honor committed to the cause of the downtrodden, only few people in his shoe would have rejected national award, but since Achebe was highly principled, he chose to stay on the side of the people. He refused to compromise on his convictions and beliefs that our leaders have not done enough to serve the people who elected them into the office. Prof. Achebe was a voice for the voiceless. He was a bona fide citizen of the world who used his pen to bring Nigeria's name into the world literary stage to blossom. His name will surely live in many hearts forever. Chinua Achebe will not be forgotten because of his humanitarian acts and emancipation of the masses. This was one of the reasons he refused to fraternize, wine and dine with the nation's political leaders whom he felt had betrayed the people through their bad attitude to governance. He personifies a renaissance of African culture. He portrayed well his gentlemanism with periscope view of African tradition, and voice, while he depicts African experience in a manner that shows our rich culture. As non-revolutionary, he brought African 
tradition into a prose genre in the same way Ola Rotimi did in his dramaturgy. In so far as he epitomizes humanity and spirit of hard work, for the entire humanity, Achebe in all his writing never wrote to please government or the establishment, he was not the type to join the band wagon or the crowd. He wrote objectively not to please anybody but only his own conscience. He remains a voice of Africa forever.

\section{Achebe a Colosus of Learning and Writing in Nigerian and African Education}

Prof. Chinua Achebe is a great Nigerian hero. He was really a literary prolific giant in writing and character and in learning Nigerian and African education. Achebe contributed immensely to education to journalism to literature, to academia and various developments. His achievements and contributions to the society are monumental. Achebe was a good voice for Africans and in particular the Nigerians. He is a seasonal crusader who daily wanted to uplift Nigeria to any height of progression and advancement.

This legendary iconic and prolific author had allowed us to truly run in his literary shoes for a better understanding of self and our ecological variables. Achebe's works have been found useful in a wide spectrum of academic disciplines. They are studied as texts for Sociology. Languages Anthropology, History, etc, when Things Fall apart was 50 years in 2008, it broke several records and the best known book by an African. Achebe, people wrote privies in his writing that words do dance, more so to the beats of a master drammer. Achebe was a pupil and student of St. Philips Central School Ogidi, Anambra State and Central School Nkede, Owerri, Imo State. He left his footprints as a very brilliant student as he obtained full scholarship to Dennis Memorial Grammar School Onitsha and Government College Umuahia. He passed the Cambridge Ordinary Level on five distinctions and one credit. The one-credit ironically was in English Literature. As the student nick-named him "Dictionary" he must have felt disappointed. He then proceeded to University College Ibadan through a nationwide entrance examination in which he was one of the best in the country. After graduating successfully and superbly got his employment with the Nigerian Broadcasting Servicing (NBS) in 1954, equally moral rapidly up the ladder and ultimately appointed Director of External Broadcasting and later left for overseas.

Clearly speaking, Nigerians especially would probably not have known Achebe's perspective in what is arguably the most lucid diagnosis and remedy of the Nigerian problem on "The Trouble with Nigeria". And indeed a most revealing account of the Nigeria - Biafra war may also have been lost in "There Was a Country" Prof. Chinua Achebe was not only a great story teller but a literary Pan-Africanist. Through his research, learning and writing, he contributed immensely in redirecting the orientation of the root of the world on their perspective of African Culture and history. He was literary saying particularly to our colonizers before your arrival, we had a story and are proud to tell it. One of the more common features in the barrage of tributes and eulogies following the news of his death is that he was a great patriot apart of course from his obvious literary feat. This is just as well because in his essays, lectures, interviews, books etc. he had continued to engage the Nigerian question by not only pointing clearly at what the problem is in "The Trouble With Nigerian" where he find the problem squarely on leadership but also by suggesting remedies. Incidentally, the story is told of a popular American Musial who chose to title his upcoming film "Things Fall Apart" and when informed that Achebe had a copyright to the title he bragged that he would pay him off and offered a million dollars which Achebe rejected, informing him that the title was not for sale not even for one hundred million dollars. Achebe would be leaving not only a legacy of principle, forthrightness, uncommon courage, classic story telling etc, but an intellectual family of a wife who is a professor of psychology, four children, two of whom are professors of history one assistant professor of medicine and the other a writer all in the USA. 
With such novels like Things Fall Apart and the Arrow of God classically these represented the typical African culture from his tribal cultural upbringing. He captured the interest of the whole world in literature. With his astonishing expressions in his books, he also captured world recognition as a giant in literature, and went further to gain the respect of the whole world. Achebe paved the way for most of the African authors both dead and alive. He is an icon in the literary world of Africa, and beyond; an authentic writer, and introduced Nigerian literature to higher learning.

It is certain and very obvious that till this moment, a lot of Nigerian writers, if not all drew inspiration from this great writer Chinua Achebe. He was a writer who was idolized by older literary school of thought and younger literary school of thought. He is writing especially the Things Fall Apart, which is widely in different languages, resonates with both the older and younger generations. The great writer truly left a mosaic of indelible moral impressions in our consciousness regarding our onus to humanity, particularly the marginalized in the society. It took the genius of Achebe to write Things Fall Apart, but the Africa of late colonialism and the whole sweep of anti-colonial struggle had provided the backdrop for the great oeuvre. Chinua Achebe was Africa's greatest writer by a mile and it was not for nothing, that Nelson Mandela often said of him, that he was the writer, whose company broke the walls of imprisonment in acknowledgment of what he meant to him. Things Fall Apart and became Things Fall Apart, we were no longer at ease, as the consequences of imported foreign influence took hold and began to replace the way of life that had served as well for continues; the subject of Achebe's sequel. Achebe's wasteful sprinkling of human idioms, proverbs, allegories and metaphors in his narratives captured literary attention and catapulted his books into the world stage where many Universities in Europe and North America began to designate them as required readings alongside Shakespeare.

He used his literary works to inspire and touch the lives of so many people around the world. Like in the words of Prof. Dora Akunyili, who positively, emotional evoked and stated that Achebe's demise leaves a void not only in Nigeria but Africa but also globally because he was one of the best novelists the world has ever produced and his legacies will forever remain evergreen. There was something modest about the man, despite his world-acclaimed success as a pioneer and writer. His works will endure through the ages and Chinua Achebe has found a worthy space in our hearts forever. This is because his humanitarian ideals of telling the "Balanced Story" of Africa makes us moved to the deep. Beyond the hypocritical gambit of writing to be identified among those who eulogized Achebe's death, there can be no greater honor to the man than to uphold those ideals that he espoused in his life, his literary works and political activism. Achebe indeed was more than a literary person and that is an aspect of his life that he shared with Professor Wole Soyinka, political activism. Achebe was a progressive minded politician and he became involved in partisan politics in 1983 and PRP party an ultra radical philosophy which Nigerians did quite understand. An encomium endlessly pours in for Achebe whose works cut across all ages and surely one of the fear Nigerians who uplifted the image of their fatherland. His immortal good works will make things not to fall against in his home as a venting eagle on the riverside iroko. And as some people opined, what more does the grout crave beyond his story.

\section{Motivational Truism of Achebe`s Life}

The literary giant, Prof. Chinua Achebe is a great inspirator and a motivator. He was a true Nigerian Ambassador, a rare-breed, an epitome of those who have led a battle against marginalization injustice, oppression and genocide; an avid writer whose works have sailed unto the four corners of the earth, a writer who has ever remained and continue to remain one of the best and greatest exports of Africa in the international literary market. 
Achebe shaped an understanding of Africa from an African perspective more than any other author. As a novelist, poet, essayist and lecturer, he was a yardstick against which generations of African writers have been judged. For all children across Africa, his books have for decades been an eye-opening introduction to the power of literature for Nadine Gardiner, a Nobel Lauret from South Africa called him the "Father of Modern African Literature in 2007 when she was among judges to award him the Man Booker International Prize in honor of this literary career. Achebe was a great warrior and a strong 'four-star general' who went to the battlefield and emerged undisputedly 'the champion'. All through his life, he was armed with necessary machinery, a 20th century writer ought to be armed wit; and truly he paid his dues perfectly well. He was an embodiment of the fight against injustice, within and without. He was a whistle blower. He blew the 'whistle' whenever it was most necessary.

His life and death was indeed a motivational truism for his country home Nigeria, African and the world at large. As the news of his death reached peoples' ears, he was branded eulogized and nick-named and branded as follows, thus: a great prophet and patriot, an Africa's own Shakespeare, a cultural catalyst, a literary giant, African Iconic Ambassador greatest Nigerian writer, Nigerian pride, African iroko and Historian. He was an accomplished Academician, a literary form, A cultural icon, an uncommon Professor, a wordsmith, a great Igbo son, a great Nigerian, a World Class citizen, a World talent and Inspirator of generations, a great mentor and Pan African scholar, a Magical writer, King of Words, and an Iroko that stands forever etc. all these are positive hearth-rooted comments of people worldwide; and this is really highly challenging and motivational truism for the world continent. He would always be remembered for his steadfastness, forthrightness and tenacity of purpose. It is good to point out that his humble background influenced his lifestyle and molded his demeanor and personality. He listened to the ideals and teachings of his parents, and earned enormous rectitude for succumbing to the worlds of the elders. As it is always said, when a person has integrity, God is ethics and morals will integrate and pride is anti-God and anti-people. It is a truism, that Achebe, passed through travails, trials, tribulations and temptations and God saw him through. He was baptized "Albert", which means "noble" and "bright". This African icon was indeed a noble personality who proved his brilliance in numerous spheres of life.

In those days when Achebe was born, education did not attract so much attention as a result of many reasons. The first and foremost, Achebe was born in a colonial period when mostly those who want to school were the children of the colonial masters and the children of the prominent Nigerians who in most cases had something in common with the colonial masters. More so, Chinua Achebe was born in an environment where emphasis was laid mostly on farming and trading with focus on wealth creation. Behold, his parents' closeness to the missionaries changed the orientation and made them to see education as a priority to farming and trading. As Nelson Mandela, one-time president of South Africa put it that is the most powerful weapon which you can use to change the world to change the world. Education actually brings knowledge, fame and wealth.

In the words of Francis Bacon, knowledge is power. Chinua Achebe was educated in every measure of it. He received early education in English. Actually Achebe wanted to study Medicine but ended up studying literature at the University of Ibadan.

He had a good mind, a mind that is literature that would enable him mirror the society and impact on the lives of many. Achebe equally used this aspect well. As Descartes opines, it is not enough to have a good mind, the main thing is to use it well. Our life on earth is not beauty but a duty. After graduating from the University of Ibadan and a subsequent teaching stint in 1961, 
Achebe joined the Nigerian Broadcasting Cooperation as director of external broadcasting, a position he held until 1966.

Things Fall Apart (1958) was his first novel. It has been translated with at lease fifty languages and has sold over ten million copies worldwide and has become the required reading in many schools across the world. The 1960s were creatively fertile period for Achebe. It was during this period that he wrote the novel No Longer At Ease (1960), Arrow of God (1966), all of which tackle the conflicts between the traditional ways of life and colonialism. His book, Anthills of Savannah 1987) dwelt on similar theme. The 1970s proved equally productive, and Achebe published several collections of short stories and children's book including How the Leopard Got His Claws (1973, Beware Soul Brother (1971), Christmas In Biafra 91973) and his first book of essays, Morning Yet On Creation Day (1975).

Achebe was a renowned social critic, an activist and a comrade. He hated bad governance as many of his novels dealt with the society and political problems facing Nigeria, including the difficulty of the post-colonial legacy. He struggles against injustice demarcated his enemies from spectators. Achebe's enemies are the bad ones in governments who promote corruption in the system and plunder the economy, leading to widespread crises, crimes, diseases and poverty.

As we pointed out before, twice the nation's government tried to honor him with the befitting and the prestigious national honor of the Commander of the Federal Republic (CFR) and twice he rejected the honors because of his displeasure with the bad governance in Nigeria and the accompanying suffering of the masses, which the leaders have failed to address. It is a known fact, on the other hand, that Achebe's spectators are the masses who suffer regularly in the midst of abundant resources caused by bad governance. Unfortunately these troubles with Nigeria addressed by this social crusader is his book, The Trouble with Nigeria could still not be attended to till his eventual death. The society therefore needs the new Achebes to continue the struggle as it is very wrong to be far in the midst of plenty. He laid a good foundation which scholars and contemporary writers should adopt. Educators, scholars and authors should write for transformation of the society like Achebedid, and should preach the good ideals of Achebe, which have endeared him to the world. The good words of Myles Munroe teaches us that, it does not matter who your grand father was, the most important issue is that your grandchildren are going to say about you. As useful and purposeful man like Achebe deserves honour at life and death. Achebe is not a mere artist that should be forgotten with ease. In all these, he made a difference in his life through his great efforts and industriousness. As Leon Rooter says, I think the purpose of life is to be useful, responsible, honorable, and compassionate and above all to stand for something, and to have made a difference that you lived at all.

One thing we learnt from Achebe's work is that, his system or modus operandi is nothing more than a collection of people, coupled with their values and their behaviors. Africa as a continent with its cultural heritage is constantly amending its story and adding new chapters.

We have as a nation and continent experienced political, cultural and digital revolutions. Those who say "beholden" to only the story of colonialism apartheid and ethnic warfare will never allow themselves to know the Africa that now also tells a story of equality, democracy and capital cities that are as crowded and cosmopolitan as those of any other continent. A great motivational truism of Achebe's person should also be that we joined the whole world to shower encomiums on this man of letters for standing out among literary giants. He took the African story, the Nigerian story, out of the apparently warped view of colonial writers, 
exemplified in Joseph Conrad and his ilk and his ink, and told it, as it ought to be. His Things Fall Apart on the consequent trilogy became classics not just in delivery but also in thematic and structural ingenuity. The works have been found useful in a wide spectrum of academic disciplines. They are studied as texts for sociology, languages, anthropology, history etc; when Things Fall Apart was 50 years of its publication in 2008, it broke several records as the best known book by an African. Achebe wrote and proves in his writing that words do dance, more so to the beats of a master drummer.

Achebe has a patriotic disposition, such as one finds out in his works and comments. In his pamphlet captioned - The Trouble with Nigeria, he spoke truth to power insisting that the real problem with his fatherland is leadership. His first home visit from his base in America, after confinement to a wheel chair via a car crash in 1990 in Nigeria, was to deliver Odenigbo lectures organized by Archbishop Obinna in Owerri Archdiocese in furtherance of Igbo language and cultures.

At this junction, as Achebe leaves this mundane world, we obvious need a Reader who is A Man of the People who will repeatedly shoot at our problems with Arrow of God atop the Anthill of a Savannah until we have not a country that was but one that is. Achebe was a noble cultural man. He propelled the Igbo culture around the world and promoted cultural awareness with his novels. He is an Iroko in the world of literature. I have read a lot of his books, including The Trouble with Nigeria. He is the conscience of the under-privileged. For Tony O. Egbe, Chinua Achebe was an African legend, who lived his life educating, not only Africans, but the rest of the world with his powerful novels of African Tradition and culture, using his examples from his Igbo Tribe traditional upbringing. But there is an irony in Achebe's rejection of National honor. In a nation where there is existence of a thing without a title is for some, as like walking naked, where some relish in titles and flaunt them with nauseating and vulgar arrogance, it attracts a deserving attention that someone is turning down his. Achebe equally turned down Chairmanship of Federal Radio Corporation of Nigeria (FRCN) when several lobbyists besieged former president Babangida for the position. The point to be made is that man has no knack for playing to the gallery, which was why few people knew about his rejection of that position in those days. Few also knew that he had once sat as Pro-chancellor of Anambra State University and walked away when his principles stood in the opposite direction with those of the military authorities. In rejecting the honor the literary Iroko was making a strong point, one he would have made to anybody.

Indeed the motivational truism of Achebe's life is great. This is shaped and manifested in all his literary cultural contexts. He had also one time explicitly made this statement thus: Here then is an adequate revolution for me to espouse to help my society regain belief in itself and put away the complexes of the years of denigration and self-abasement, so, the voice of a most illustrious ancestor whose guttural wisdom will accompany us till we draw our last breath is evidence. Since Chinua Achebe's passage, some of his close friends and associates have had long occasional spells of uncertainty; moments where news of his death sounded one of the many cruel joke. Our politicians play on their opponents, announcing their deaths in the special media to cause them a little discomfort. Indeed through his motivational spirit, he had left us a body of works to guide our slow, cautionary, steps in a world where prejudices lay ambush at every turn, where the story-teller has much power to heal as to kill and after he had left his testament in that monumental book-There Was a Country.

\section{CONCLUSION}

One will say at this juncture that the African legend and literary icon won not only the love but also the heart and respect of most elites especially the academia globally. 
He really embellished and increasingly improved our knowledge of African culture and tradition through his research and pen apostolate. Some other legends are Mphahlele, Coetzee, Wole Soyinka, Ngugi, John Munonye and other University teachers/writers who did maintain relevance in post-colonial Africa's literary and cultural scholarship. They taught us how to be a creative writer and avid researcher. For Joseph Ushic and Denja Abdullahi in the book Things Fall Apart "But the Centre Holds ", opined that many African writers seemed at the inception of AWS African Writers Series, were far more overwhelmed with the ideals of integrity and did maintain a sense of moral authority as the continents cultural ambassadors. Chinua Achebe the novelist and teacher, were, and still as a legend occupy a frontal position in that emancipational struggle. As he Prof. Achebe rightly observes, we have yet to overcome the "disaster brought upon the African psyche in the period of subjection" despite independence. I would add that independence, as the trauma of the colonial voiding of our will to determination, repeats, that could exacerbates that original catastrophe. The result is the unbroken cycle of "acting-out", of puzzling behavior in the political sphere clearly denied today by shocking impunity and corruption.

Achebe's name will last longer in life, his name will last longer than a thousand hoards of gold. The days of a good life are numbered but a good name last forever. (Ecctes or (Sirach) 41:1113). He is a rare writer of sublime flawlessness and he took his place among the greatest like Homer, Pushkin, Shakespeare and other great writers. For some erudite on the emerging perspectives on Achebe's the Africa's master story teller and pioneer literary philosopher of 20th century remains reigning for very many years to come. He is indeed a great artist, who has influenced for the better, the course of world literature in English not only for his generation but for eternity; a writer who through his works, has touched and changed many lives; African novelists who has provided a renewed sense of African heritage, history and tradition.

Actually, the challenge of pointing the way forward for an African society freshly extricated from the shackles of colonialism necessitated the persistent request for a blend of aestheticism and utilitarianism in the literary work. It is for this reason, that the issue of the African writer and the question of commitment preoccupied a large number of Africa's literary intelligentsia for over two decades. It is the motivating force behind Achebe's earlier statement and rudimentary essays on the role and responsibility of the African writer, Soyinka's similar proclamation that the artist has always served as the voice of vision in Africa, as well as Ngugi's consistent declamation of neo-imperialism in Kenya.

The publication of the Trouble with Nigeria instantly lent many a rare insight into the philosophical flaws that marred the formation of a truly responsible and accountable leadership in Nigeria. We learned for instance that while their contemporary were sculpting crucial ideological foundation for emerging African countries, our finding father were expressing a crass wish to accumulate enormous wealth and enjoy the highest standards of living. On these challenging points, many viewed it that an absence of objectivity and intellectual rigor at the critical moment of a nation's formation is more than an academic matter. It inclines the fledging state to disorderly growth and mental deficiency. Achebe had reasoned well in the Trouble with Nigeria. He meant well for all, especially, that we organize ourselves formidable intellectually, morally invulnerable for all, we can with our brain and brawn to make Nigeria and African continent great.

As his royal and colorful burial took place on 23 May, 2013, his wife and all lovers of Achebe should ever more continue to thank God for his good life and dexterity in ideal of grieving that he did not win the Noble Price in Literature. The possibility of his winning this posthumously is 
there. When this eventually happens, he will join Dag Hawnarskjold, Swedish detonating and second secretary general of the United Nations in 1961, who received the Nobel Prize after their death. None the less, for the Nigerian citizen, the greatest honor to Chinua Achebe is to avoid those things Achebe really abruptly and precipitously hated and wrote against. Heavily eulogizing the icon by especially by those in government is not enough and would yield no fruit for the citizenry. It will be rather doing what Achebe hoped for, which he presented in his writings. It's about fighting injustice, corruption and catering to the needs of the unhappy children of God and the downtrodden. It is most importantly on being human and living up to the expectation for the "bonum commune" good of everybody.

He remain our Nigerian-Africa warrior and undisputed champion. Prof. Chinua Achebe, is the man with stories, "Ugobelun'enuoji" - the eagle on the iroko. We will continue ever more to cogitate over both the story and the story teller; from Things Fall Apart, Arrow of God etc; coupled with all other numerous articles and poets as an avid reader and educationist. He will forever personify the ever fresh renaissance of African thought and culture, coupled with his strong periscopic view of African tradition and voice. As a legendary iconic prolific giant in writing and character and in learning Nigerian and African education, he remain our pace setters in many ways. Let the challenges he set for us be a food for thought on a wide spectrum of academic disciplines which touches and connotes our other ways of living for the advance of our nation and African cultural heritage in general.

\section{References}

Achebe, Chinua. Things Fall Apart, London, Heinemann, 1976, p. iii

Folashade, Adebajo. Tell Magazine, Nigeria and There Was Achebe, April 1, 2013, p.18.

New York, State Resolution “Full Text of Resolution” J1186-2013: Legislation Resolution Morning the death of paramount novelist Chinua Achebe, Founder and Pioneer of African Literatures.

Ushie, J, et al., (Ed), Themes Fall Apart but the Centre Holds, Association of Nigeria, Authors, Publ. Lagos, 2009.

Medien Newspapers: Sunday Sun, March 5, 2013, p. 5.

Daily Sun, March 28, 2013, p.25.

Daily Sun, March 29, 2013, p.56-57.

Saturday Sun, March 30 2013, p. 43.

Daily Sun, April 4, 2013, p. 19.

Daily Sun, May 9, 2013, p. 23.

Daily Sun, May 26, 2013, p. 46.

Daily Sun, May 30, 2013, p. 23.

Vanguard, March 28, 2013, p.17.

Vanguard, March 28, 2013, p.55.

Vanguard, April 18, 2013, p.4.

Vanguard, April 22, 2013, p. 6.

Vanguard, April 22, 2013, p. 13.

Vanguard, April 22, 2013, p. 19. 